\title{
ВІЙСЬКОВА ДИСЦИПЛІНА ЯК КОМПОНЕНТ ПСИХОЛОГІЧНОЇ ГОТОВНОСТІ ОСОБИСТОСТІ ДО АРМІЙСЬКОї СЛУЖБИ
}

У статті порушено проблему психологічної готовності військовослужбовиів Збройних Сил Украӥни до службово-бойової діяльності. Акцентується увага на питаннях додержання військової дисиипліни й розвитку свідомої дисциплінованості солдатів. 3 'ясовано, щяо високий рівень дисципліни й сформованість такої риси як дисциплінованість є важливими показниками якості військового професіоналізму, що впливають на успішність виконання бойових завдань.

Ключові слова: поведінка військовослужбовців, дисциплінованість, військова дисципліна, профілактика правопорушень, службово-бойова діяльність, військова психологія, психологічна готовність.

The article deals with the problem of psychological readiness of servicemen of the Armed Forces of Ukraine to military service. Emphasis is placed on adherence to military discipline and the development of the conscious discipline of soldiers. The content of the concepts of «discipline» and «discipline» is analyzed and the ways of achieving military discipline are outlined. It has been found that high level of discipline and traits such as discipline are important indicators of the quality of military professionalism that affect the success of military missions.

It is emphasized that women are still subject to gender stereotyping, despite their active integration into the military subculture. Existing gender-based stereotypical perceptions of female servicemen contrast sharply with the qualities necessary for successful military service in the military subculture.

It is shown that the qualitative characteristic of psychological readiness for professional activity contains a personal component, which includes the individual qualities that make up the content of qualification characteristics of employees of paramilitary structures. Among the broad range of these qualities, discipline is seen as a leading feature of the military personality and the foundation of the military environment.

Questionnaires were analyzed to investigate the psychological preparedness of soldiers. It is revealed that one of the important criteria is the level of disciplinary violations in the unit. The main content of which is that discipline is about respect and disrespect for disciplinary rules and is an indicator of general relationships in the unit. It has been found that a disciplined person has an impeccable responsibility in the performance of his or her duties, able to manage his or her behavior and actions, to comply with oath and military statutes, as well as orders and orders of commanders and commanders in any situation.

It is justified to continue scientific research in the field of methodology for organizing the process of purposeful formation of professionally important qualities and disciplinary motivation for servicemen, which ensures the fulfillment of difficult tasks in times of peace and war.

Keywords: behavior of military personnel, discipline, military discipline, prevention of offenses, combat service, military psychology, psychological readiness.

Постановка проблеми. Суспільство завжди наділяло військових такими позитивними якостями, як мужність, витривалість, впевненість, рішучість, цілеспрямованість тощо. Проте їх винятковими характеристиками, на яких варто акцентувати увагу, є свідома дисциплінованість та висока організованість, що зумовлює високі результати службової діяльності й належне виконання 
бойових завдань в умовах мирного й воєнного часу. Таким чином військова дисципліна вважається головною підвалиною армійського середовища, додержання якої обов'язкове для кожного військового, незалежно від його особистісних якостей чи гендерних особливостей. Під час підготовки солдатів важливо формувати у них усвідомлене ставлення до військової дисципліни. Цьому сприяють щоденний розпорядок і статутні вимоги, з якими стикаються новобранці вже при першому знайомстві з армісю.

Прикметно, що цивільні особи теж надають великого значення порядку й організованості у житті, позаяк це допомагає їм максимально оптимізувати й структурувати свою активність, а також почуватися впевнено та захищено. Позитивна динаміка зростання економічної могутності України, покращення іiі інноваційного розвитку та впровадження низки важливих реформ залежить насамперед від ефективності роботи органів державної влади, додержання законності та дисципліни в усіх сферах суспільного буття.

Аналіз останніх досліджень і публікацій. У контексті зазначеної проблематики тривають міждисциплінарні студії дисциплінованої поведінки на стику філософії, історії, літературознавства, юриспруденції, педагогіки та психології, які розглядають ï як соціально-психологічне та культурно-історичне явище.

Сучасна система роботи щодо зміцнення військової дисципліни базується на ідеях античних філософів, а також відомих істориків і полководців, у працях яких обгрунтовано принципи науковості, оптимізації, гуманізації, демократизації, об'єктивності та повноти інформації, правильного добору та використання кадрів, ініціативи та активності.

Доволі грунтовно у світовій науковій літературі висвітлено історичний військовий досвід козацьких формувань [3], зокрема, розкрито внутрішні чинники функціонування козацтва, цінності та риси характеру запорізьких козаків (I. Кравченко, В. Щербак, А. Скальковський, Д. Яворницький), сутність козацького аскетизму та лицарства (М. Дубецький, Т. Чарновський), систему фізичного та військового виховання у Січовій школі (С. Сірополко). Загалом, британські, французькі, польські та інші зарубіжні історики дуже високо цінували військову звитягу і моральні цінності козаків, порівнюючи їх 3 вікінгами, тевтонськими рицарями, мечоносцями, іспанськими магілетами, шотландськими горцями, спартанцями та римлянами, а козацьку республіку з республіками Спарти й Риму (Н. де Бартеон, Б. Коннф, Ш. Лезюр, П. Меріме, Й. Мюллер, А. Сокур, Ж.-Б. Шерер та ін.). Такі дослідники, як П. Меріме та Дж. Вернадські переконані, що Запорізька Січ була своєрідною школою лицарства та мужності, тому запорожці цілком справедливо можуть називатися лицарями.

Згадуючи про «білі плями» в історії України, ми відкриваємо для себе майже забуту історію українського війська. Йдеться про військове будівництво Збройних Сил УНР, становлення системи військового вишколу та виховання в українській Армії, у тому числі й в школах УПА. Окремої уваги тут заслуговує аналіз процесу розвитку національної свідомості та військової дисципліни солдатів. Все це актуально не лише з огляду на потребу вивчення історії 
Збройних Сил України, але й у контексті російсько-української війни на Донбасі, реформування ЗСУ та створення професійної армії майбутнього за стандартами НАТО.

Відомі вітчизняні фахівці в галузі військової психології зазначають, що однією з основних складових виховної роботи в ЗСУ є морально-психологічне забезпечення дисципліни та профілактика правопорушень (М. Варій, М. Бабенко, М. Карманов, В. Клименко, В. Ягупов та ін.) [1]. 3 цією метою розроблено керівні документи, в яких містяться вимоги щодо організації виховної та соціально-психологічної роботи, спрямованої на зміцнення військової дисципліни, а також визначено технології впливу на свідомість і поведінку військовослужбовців.

Нині процес психологічного супроводу військової дисципліни здійснюється у руслі індивідуально-особистісного, управлінського та колективно-групового підходів. До основних напрямів діяльності керівного складу військової частини щодо зміцнення військової дисципліни та профілактики правопорушень належать: індивідуально-виховна робота з різними категоріями особового складу, профілактика правопорушень і дисциплінарна практика [2; 7].

За даними наукових досліджень, розроблено критерії, за якими оцінюється військова дисципліна, також з'язовано, що іії порушення вирішальною мірою залежать від індивідуально-психологічних властивостей особистості. Зарубіжні дослідники переконані, що дисципліна - один із елементів психологічної бойової готовності сучасних воїнів - стосується, насамперед, поваги (або неповаги) до дисциплінарних правил і $є$ важливим показником взаємин у підрозділі. Водночас слабка військова дисципліна належить до чинників, які зумовлюють різні форми девіантної поведінки, серед яких особливе місце посідають зловживання алкоголем та вживання наркотиків в армії. Згідно 3 відомою мотиваційною теорією потреб А. Маслоу, військову дисципліну відносять до потреби у безпеці [5].

Попри те, що військова психологія має чимало напрацювань у цій царині, науковий інтерес до проблеми військової дисципліни посилюється, що зумовлено великою кількістю збройних конфліктів у світі. За словами Н. Коупленда [6], дисципліна й моральний дух солдатів є таємною зброєю будь-якої держави. У такий спосіб він визначав військову дисципліну як основну складову морального стану й бойової майстерності військ.

Мета і завдання дослідження: вивчити особливості становлення та розвитку дисциплінованості військовослужбовців, обгрунтувати важливість формування у солдатів усвідомленого ставлення до військової дисципліни, що обумовлює їх психологічну готовність до ефективних дій у повсякденних та в екстремальних умовах.

Для вирішення поставлених завдань було використано такі методи: теоретичні (аналіз, синтез, порівняння, систематизація та узагальнення представлених у науковій літературі концептуальних положень 3 досліджуваної проблеми), організаційні (порівняльний метод) та інтерпретаційні. Методологічне підгрунтя дослідження становлять функціональний підхід до визначення змісту 
психологічної готовності, який трактується як певний стан психічних функцій, що зумовлює високий рівень досягнень під час виконання певного виду професійної діяльності, та особистісний підхід, який тлумачиться як сукупність психологічних утворень, принципів і понять, способів мислення, відповідних умінь і навичок, мотивів, якостей особистості, що забезпечує здатність до здійснення професійної діяльності.

У структурі психологічної готовності до професійної діяльності військовослужбовців виокремлено емоційно-вольовий та особистісний компоненти. Змістове наповнення першого передбачає мобілізацію сил відповідно до умов професійної діяльності, що проявляється через самоконтроль, самонавіювання в процесі досягнення цілей, саморегуляцію дій, подолання сумнівів, страхів, уміння зосереджуватися на завданнях тощо. Особистісний компонент являє собою поєднання важливих для здійснення ефективної військово-бойової діяльності стійких індивідуально-психологічних особливостей військовослужбовців. Йдеться передусім про високий рівень дисципліни й сформованість такої риси, як дисциплінованість. Ці показники визначають якість військового професіоналізму, що впливає на успішність виконання бойових завдань.

Виклад основного матеріалу. У зв'язку з предметом нашої теоретичної розвідки з'ясовано, що існує безліч історичних прикладів ролі військової дисципліни в перемозі над ворогом [3]. Так, наступ мільйонної армї перського царя Дарія (IV-III ст. до н. е.) зупинило кількатисячне військо греків, бо перша була мультинаціональною й складалась із невільників-рабів зі всього світу, які не поділяли інтересів Дарієвої держави. Відтак дисципліна у війську підтримувалась виключно погрозами та нагаями, що пригнічувало його бойовий дух.

Для українців козацький рух є яскравою сторінкою літопису боротьби нашого народу за свою незалежність. Як зазначав С. Старовольський, попри те, що єдиних критеріїв відбору молодих козаків не існувало, вони мали у своїх таборах дисципліну стародавніх римлян, а воєнною мужністю та досвідом не поступалися жодній нації в світі. За дослідженнями Ж.-Б. Шерера, відмінність між козацькою республікою та республіками античності полягала в тому, що громадяни козацької республіки ніколи не готувалися до завоювання чужих земель, а лише прагнули до захисту своїх, обстоюючи право на свободу. За дослідженнями науковців, запорожці створили систему надзвичайно ефективних спеціальних фізичних і психологічних вправ, що спрямовані на самопізнання, саморозвиток, самовиховання, тілесне, психофізичне та моральне вдосконалення воїна. Прикметно, що й понині ця система викликає інтерес у наукових колах, позаяк вважається однією з найкращих у світі.

Загалом, вся історія розвитку та існування виду гомо сапієнс (людини розумної) так чи інакше пов'язана з дисципліною. Елементарні форми останньої помічено вже у первісному суспільстві. Її головним мотивуючим чинником $\mathrm{i}$ санкцією, що підтримувала відповідну поведінку, виступав страх людини перед вигнанням із племені та небезпекою загинути голодною смертю. Водночас, зазначимо, що лише з утворенням держави дисципліна стає невід'ємним атрибутом влади й поступово набуває суспільної цінності. Таким чином, заро- 
дження дисципліни та їі перетворення в соціальне явище зумовлено двома причинами: по-перше, необхідністю досягнення певних державних цілей в усіх сферах життя, що об'єктивно вимагало високої організованості великих груп людей, різних за своїм соціальним та етнічним складом; по-друге, прагненням правлячих еліт до свідомого утримання в покорі та порядку значної частини чоловічого населення.

У словнику поняття «дисципліна» тлумачиться у подвійному розумінні як самостійна галузь якої-небудь науки та як обов'язкове для всіх членів певного колективу підпорядкування твердо встановленому порядку; витримка, звичка до повного порядку. Згідно з останнім визначенням, у соціально-психологічному аспекті дисципліна $є$ ступенем відповідності реальної поведінки й діяльності людини загальноприйнятим культурним традиціям, груповим нормам та очікуванням, а також вимогам державних законів і локальних правових актів тієї чи іншої інституції. Як специфічний механізм регуляції взаємин між людьми, вона являє собою інтеграцію двох компонентів: об'єктивного (виконання вимог, що висуваються соціальним оточенням) і суб'єктивного (інтеріоризація затверджених вимог та їх усвідомлене виконання). Між цими компонентами утворюються діалектично суперечливі зв'язки й залежності, які за своїм змістом, з одного боку, мають загальний характер, а $з$ іншого - завжди винятково індивідуальні.

У зв'язку 3 цим, поряд із поняттям «дисципліна» в науці використовується поняття «дисциплінованість», що відбиває комплексну, унікальну якість індивіда, яка виражається в його принциповому ставленні до різних елементів дисциплінарної системи. Ми погоджуємось з науковцями в тому, що дисциплінованість слід розглядати як важливу вольову рису характеру людини, від якої залежить якість їі життя. Посівши чільне місце у формуванні особистості, ця риса допомагає утримуватися від неадекватних бажань, що суперечать спільним інтересам або можливостям їх виконання, дотримуватися загальних вимог колективу та виконувати встановлені правила співіснування в ньому. Зрозуміло, що позитивних результатів можна досягти лише за умови довготривалої, регулярної, цілеспрямованої та самостійної підготовки, яку не кожен здатен витримати. Водночас, якщо людині притаманні дисциплінованість та організованість, то вона матиме набагато більші шанси на успіх у житті.

До основних трьох груп критеріїв, які беруть до уваги вітчизняні дослідники, оцінюючи ступінь розвитку дисциплінованості, належать: 1) рівень розвитку суб'єктності, що має відношення до свідомого самостійного вибору й ухвалення рішень; 2) рівень сформованості вольових якостей, що обумовлюють цілепокладання, відповідальне виконання, наполегливість, самоконтроль тощо; 3) системи цінностей, на які людина орієнтується у виборі типу і способу поведінки, та мотивів як спонук діяльності. Таким чином дисциплінованість визначається рівнем самодетермінації, яка зумовлює усвідомлене та відповідальне виконання тих чи інших вимог діяльності.

Розглянемо тлумачення дисципліни 3 погляду військової психології. У зв’язку з цим згадується відома максима, що недисципліноване військо 
створює загрозу оточуючим, бо перетворюється на погано керований натовп. Водночас сувора військова дисципліна робить з армії дійсно ударну, бойову силу, що викликає у звичайних людей почуття поваги та гордості, а у ворогів страх і зневіру. За приклад, гідний наслідування, може слугувати стиль життя військовослужбовців, що передбачає самовиховання, організованість та дисциплінованість.

Проте не треба забувати, що існують гендерно зумовлені стереотипні уявлення про жінок-військовослужбовців, які різко контрастують 3 якостями, що необхідні для успішного проходження військової служби. Так, за даними американських дослідників, в армійському середовищі широко розповсюджена думка, що типовий чоловік легше приймає рішення, більш дисциплінований, незалежний, впевнений у собі й порівняно з середньостатистичною жінкою має яскраво виражені лідерські якості. Натомість типові жінки більш поступливі, добрі, лагідні та емоційно експресивні, ніж чоловіки. Як бачимо, попри те, що спостерігається активна інтеграція жінок в армійську субкультуру, вони, як i раніше, стають об'єктом гендерної стереотипізації. С. Сорчер вважав, що головними причинами цього є законодавча політика, яка обмежує участь жінок у бойових діях, та кількісні показники, які свідчать про низький відсоток жінок в армії [9].

Слушним є застереження Н. Коупленда [6], що дисципліна є показником загальних взаємин у підрозділі, тому іiі головне призначення - згуртування індивідів в організований колектив, усі члени якого за необхідності діятимуть злагоджено, утворюючи єдине ціле. Такий підхід є цілком виправданим i відповідає сучасним вимогам до якості військової підготовки, оскільки його застосування в складних бойових умовах дозволить безперешкодно досягти поставлених цілей.

У Законі України «Про Дисциплінарний статут Збройних Сил України» зазначається, що військова дисципліна - це бездоганне і неухильне додержання всіма військовослужбовцями порядку і правил, встановлених військовими статутами та іншими законодавчими актами України; вона грунтується на усвідомленні військовослужбовцями свого військового обов'язку, відповідальності за захист Вітчизни, незалежності та територіальної цілісності України, на їх вірності Військовій присязі [4]. Тимчасом як дисциплінованість - це універсальна якість особистості військовослужбовця, роль якої полягає в саморегуляції та самоорганізації іiі поведінки у відповідності із статутними нормами, вимогами та правилами, свідомому дотриманні норм і правил військового етикету. Йдеться про здатність людини у будь-якій обстановці вміти керувати своєю поведінкою й діями, виконувати вимоги присяги та військових статутів, а також накази та розпорядження командирів і начальників, виявляти бездоганну відповідальність під час виконання службових обов'язків.

У статті 3 ДС ЗС України окреслено шляхи досягнення військової дисципліни [4], зокрема: виховання високих бойових і морально-психологічних якостей військовослужбовців, їх особистої відповідальності за дотриманням Військової присяги; формування правової культури; поєднання вимогливості 
командирів і начальників до підлеглих без приниження особистої гідності останніх, з дотриманням прав і свобод, виявом постійної турботи про них; зразкового виконання командирами військового обов'язку, їх справедливого ставлення до підлеглих; підтримання у частинах (підрозділах) необхідних матеріально-побутових умов i статутного порядку; своєчасного i повного постачання встановленими видами забезпечення; чіткої організації бойового навчання.

Як було сказано вище, високий рівень дисципліни й сформованість такої риси як дисциплінованість вважаються важливими показниками якості військового професіоналізму, що впливають на успішність оволодіння технологією службово-бойової діяльності. Науковці виокремлюють два види дисципліни колективу та особистості. Стосовно першої, то за словами бригадного генерала А. Гендерсона, в погано дисциплінованій армії вкрай низька мобільність. Водночас високодисципліновані війська під час наступу проявляють дива військової звитяги. Таким чином згуртований колектив здійснює потужний мобілізуючий вплив на дисциплінарну поведінку військовослужбовців. Відтак основне завдання командира полягає в тому, щоби забезпечити спрямування соціально-психологічного потенціалу військового підрозділу у відповідне русло.

Е. Утлік [8], запропонував загальну схему такої роботи, яка передбачає взаємодію таких трьох компонентів групової психології: 1) внутрішньогрупові ролі, традиції та звичаї; 2) внутріщньоколективні правила та норми поведінки; 3) ідейно-моральні цінності суспільної свідомості.

Як бачимо, щоби досягти високої бойової могутності, армія має стати високодисциплінованою. Поведінка окремих солдатів безпосередньо впливає на стан військової дисципліни підрозділу і частини. Втім, високий рівень дисциплінованості досягається не внаслідок покарання за помилкові дії, а завдяки свідомому бажанню військових бути готовим до правильного виконання поставлених завдань. 3 цього приводу у своїй книзі «Десять заповідей управління кораблем» капітан 1-го рангу Р. О’Конор зазначав, що кожному офіцерові та матросу треба довіряти й у разі скоєння ними першого правопорушення не вбачати в цьому злого умислу, а розцінювати це як результат незнання або неуважності. При повторному вчиненні такого діяння відповідальні особи мають діяти рішуче і жорстко, бо на їхньому боці флот, дисциплінарний статут і парламент. Тут згадується золоте правило військової дисциплінарної практики - брати до уваги дрібниці, й тоді не виникне труднощів у вирішенні важливих питань.

Концепція дисципліни завжди формується під впливом певної теорії, що обумовлює характер практичних дисциплінарних вимог. У цьому зв'язку зазначимо, що структура i зміст механізму регуляції поведінки особового складу ЗСУ представлено, як сукупність трьох важливих елементів:

1) індивідуально-особистісної дисциплінованості (притаманна кожному військовослужбовцю, незалежно від звань і займаних посад);

2) колективної дисциплінованості (є властивістю добре організованого й вихованого військового підрозділу, що виробляє свої внутрішні соціальнопсихологічні механізми порядку); 
3) мистецтва дисциплінарного управління (становить сутність воєннопрофесіональної компетентності командира).

Ці три елементи знаходяться в тісному взаємозв'язку, позаяк військова дисципліна створюється як кожним окремим військовослужбовцем, так і колективними вчинками підрозділу загалом.

Свого часу хорватські військові психологи на основі спостережень та пілотних досліджень склали анкету, за допомогою якої можна дослідити психологічну бойову готовність солдатів (ПБГ). У військовій психології під цим поняттям розуміють стосунки між людьми у підрозділі, відносини 3 командиром та інші прояви згуртованості. ПБГ-анкета охоплює вісім критеріїв, серед яких виокремлено рівень дисциплінарних порушень у підрозділі. Основний зміст якого полягає в тому, що дисципліна стосується поваги і неповаги до дисциплінарних правил і $є$ показником загальних взаємин у підрозділі. Поява бійок, крадіжок, пияцтва, проявів дезертирства, саботажу тощо свідчить про слабку згуртованість військового колективу, що матиме негативний вплив на поведінку індивіда не тільки у повсякденному солдатському побуті, але й на полі бою. За словами одного із військових, «якщо мене соціальна група не примушує до виконання певних правил, і якщо від мене не очікують відповідальності щодо неї, тоді, я вважаю, що ця група мене не прийняла як свого члена» [5].

Таким чином у системі забезпечення військового порядку норма дисципліни слугує орієнтиром для планування індивідуальних та групових вчинків воїнів. Це означає, що плануючи якийсь учинок, воїн мимоволі співвідносить його 3 тим, як до цього поставляться його товариші по службі. І якщо він сподівається на їх моральну підтримку, то це може стати вагомим аргументом на користь здійснення даного вчинку. 3 іншого боку, запропонована норма $\epsilon$ критерієм оцінки поведінки воїна, що допомагає всім іншим виробити власне ставлення до тієї чи іншої події у підрозділі, спираючись на ці усереднені оціночні судження.

Норма дисципліни виникає в колективі на грунті накопиченого досвіду і традицій поведінки. За нею стоять поширені серед особового складу погляди на дисципліну, іiі значення та роль під час служби. Це означає, якщо в підрозділі вже мали місце серйозні порушення або навіть військові злочини, то треба очікувати скоєння чогось подібного за тяжкістю провини. I, навпаки, в благополучному підрозділі навіть не дуже серйозне порушення може розцінюватися як грім з неба, що сигналізує про необхідність вжиття заходів відповідного реагування. Разом із тим характер норми визначається не так самими порушеннями, як ставленням, що склалося до них у колективі, а це здебільшого залежить від особистості порушників і від ставлення до них побратимів.

Внутрішньоколективні традиції та звичаї можна розглядати як компоненти самодисциплінування. На відміну від вимог Статуту, що надходять у підрозділ як вказівки зверху, традиції народжуються переважно всередині колективу, тому займають теж місце, що й звички у житті кожного його представника. Останні означають, що з певних причин людина постійно відтворює той чи інший спосіб реагування, особливо не замислюючись над цим. Зі 
сказаного випливає, що армійські традиції мають ознаки стабільності у здійсненні деяких форм дисциплінованої поведінки. Так, у підрозділі можуть утвердитись традиції високої якості виконання завдань вартової служби, організованого прийому новобранців тощо.

На практиці додержання суворої дисципліни можливе за умов:

1) керівник знає кожного свого підлеглого, і навпаки;

2) керівник обов'язково солідаризується з колективом;

3) вся група згуртована в колектив, натхнений ентузіазмом керівника;

4) група пройнята високим духом товариства;

5) колектив добре навчений, енергійний та ініціативний.

Якщо створити перелічені вище умови в різних сферах життя, в тому числі й у військовій, то це буде запорукою їх успіху, дисципліни та порядку.

Висновки 3 даного дослідження i перспективи подальших розвідок. Якісна характеристика психологічної готовності до професійної діяльності містить особистісний компонент, до якого входять індивідуальні якості, що становлять зміст кваліфікаційних характеристик працівників воєнізованих структур. 3-поміж широкого спектру цих якостей дисциплінованість розглядається як провідна риса особистості військового й підвалина армійського середовища. 3'ясовано, що дисциплінована особистість виявляє бездоганну відповідальність під час виконання службових обов'язків, здатна у будь-якій обстановці керувати своєю поведінкою та діями, виконувати вимоги присяги та військових статутів, а також накази та розпорядження командирів і начальників. Відтак, вважаємо, що необхідно продовжувати наукові розвідки у царині методології організації процесу цілеспрямованого формування у військовослужбовців професійно важливих якостей та дисциплінарної мотивації, що забезпечує виконання складних завдань в умовах мирного і воєнного часу.

1. Бабенко М. С., Ротань М. П. Морально-психологічне забезпечення військової дисципліни та профілактика правопорушень. Київ, 2000. 206 с.

2. Безбах В. Г., Клименко В. С., Кубіцький С. О., Мацагор О. А. Організація виховної роботи в підрозділах Збройних Сил України : навчальний посібник. Київ, 2011. 508 с.

3. Войтович Л., Овсінський Ю. Історія війн і військового мистецтва : в 3-х т. Харків, 2017. $894 \mathrm{c.}$

4. Закон України «Про Дисциплінарний статут Збройних Сил України». URL: https://zakon.rada.gov.ua/laws/show/551-14 (дата звернення: 04.06.2019).

5. Комар 3. Психологічна стійкість воїна : підручник для військових психологів. Київ, 2017. 184 c. URL: http://shron1.chtyvo.org.ua/Komar_Zoran/Psykholohichna_stiikist_voina.pdf (дата звернення: 03.08.2019).

6. Коупленд Н. К. Психология и солдат. Москва, 1991. 96 с. URL: http://arta46.narod.ru libr/copeland/copeland1.htm (дата звернення: 23.07.2019).

7. Психологія екстремальної діяльності : навч. посіб. / І. І. Приходько, О. С. Колесніченко, О. В. Тімченко та ін. / за заг. ред. проф. І. І. Приходька. Харків, 2016. 571 с.

8. Утлик Э. П. Психология воинской дисциплины : учебно-методическое пособие. Москва, 1996. $165 \mathrm{c}$.

9. Sorcher S. How Military's 'Bro' Culture Turns Women Into Target. National Journal. Sept. 5. 2013. URL: http://www.nationaljournal.com/magazine/how-the-military-s-bro-culture-turnswomen-into-targets-20130905 (дата звернення: 12.07.19). 


\section{References}

1. Babenko, M.S., Rotan, M.P. (2000). Moralno-psykholohichne zabezpechennia viiskovoi dystsypliny ta profilaktyka pravoporushen. Kyiv. [in Ukrainian].

2. Bezbakh, V.H., Klymenko, V.S., Kubitskyi, S.O., Matsahor, O.A. (2011). Orhanizatsiia vykhovnoi roboty $v$ pidrozdilakh Zbroinykh Syl Ukrainy: navchalnyi posibnyk. Kyiv. [in Ukrainian].

3. Voitovych, L., Ovsinskyi, Yu. (2017). Istoriia viin i viiskovoho mystetstva. (Vols. 1-3). Kharkiv. [in Ukrainian].

4. Zakon Ukrainy «Pro Dystsyplinarnyi statut Zbroinykh Syl Ukrainy». Retrieved from https://zakon.rada.gov.ua/laws/show/551-14. [in Ukrainian].

5. Komar Z. Psykholohichna stiikist voina: pidruchnyk dlia viiskovykh psykholohiv. Kyiv, 2017. 184 s. Retrieved from http://shron1.chtyvo.org.ua/Komar_Zoran/Psykholohichna_ stiikist_ voina.pdf. [in Ukrainian].

6. Kouplend N.K. (1991). Psykholohyia y soldat. Moskva. Retrieved from http://arta46. narod.ru/libr/copeland/copeland1.htm. [in Russian].

7. Prykhodko, I.I., Kolesnichenko, O.S., Timchenko, O.V. et all. (2016). Psykholohiia ekstremalnoi diialnosti: navch. posib. I.I. Prykhodka (Ed.). Kharkiv. [in Ukrainian].

8. Utlyk, E.P. (1996). Psykholohyia voynskoi dystsyplyny: uchebno-metodycheskoe posobye. Moskva. [in Russian].

9. Sorcher, S. (2013). How Militarys Bro Culture Turns Women Into Target. National Journal. Retrieved from http://www.nationaljournal.com/magazine/how-the-military-s-bro-cultureturns-women-into-targets-20130905. [in English].

\section{УДК 159.9 \\ doi: 10.15330/psp.24.112-120}

Наталя Пенькова, Вікторія Шевченко

\section{ПРОБЛЕМИ СОЦАЛЬНО-ПСИХОЛОГІЧНОЇ АДАПТАЦІЇ КУРСАНТІВ НАЦІОНАЛЬНОЇ ГВАРДІЇ УКРАЇНИ ДО НАВЧАННЯ}

У статті розкрито поняття «адаптація», «соиіально-психологічна адаптація», «професійна адаптація». Проаналізовано основні підходи до виокремлення основних проблем соціально-психологічної адаптації. Розглянуто етапи соціально-психологічної адаптації. Описано етапи адаптації які притаманні саме курсантам. Виділено зовнішні та внутрішні фактори професійної адаптації. Перераховано складові професійної адаптації. Зроблено висновки в яких висвітлено основні проблеми, які заважають курсантам швидко адаптуватися до умов навчання.

Ключові слова: адаптація, сочіально-психологічна адаптація, проблеми, етапи adanmaųiï.

Based on the analysis of domestic and foreign sources, the article considers the definition of the concept of adaptation and socio-psychological adaptation. The basic levels of adaptation of cadets to the conditions of study in the military higher education are revealed: 1) partial adaptability; 2) sufficient adaptability; 3) full adaptability. The basic approaches of the Ukrainian scientists in the study of social and psychological adaptation of cadets are considered.

The concept is introduced: social and psychological adaptation of the cadets of the National Guard of Ukraine is the process of acquiring them social and psychological status, mastering certain social role functions as a result of adaptation to new living conditions, new people and values. There were four stages of social and psychological adaptation of cadets: preparatory or vocational guidance (the stage of professional self-determination of entrants, related to the 